\title{
ENHANCE SECURITY AWARENESS OF THE VESSEL'S CREW DURING TRANSITING HIGH RISK AREA (CASE STUDY ON BOARD MT. BULL SULAWESI)
}

\author{
Cahya Fajar Budi Hartanto, M.Mar., M.Si. ${ }^{1)}$; Rio Adhy Charaka, A.Md. ${ }^{2)}$ \\ 1) Lecturer at Akpelni Semarang, fajar@akpelni.ac.id \\ 2) Alumnus of Akpelni Semarang, rio.rawk@gmail.com
}

\begin{abstract}
This paper is focused on the increasing security awareness of vessel's crew to meet with the increasing of pirate activities in High Risk Area especially on Arabian Sea. Methodologies used are observation, interview, and library study. Observation was made during 12 months on board MT. Bull Sulawesi, a crude oil tanker operated by PT. Gemilang Bina Lintas Tirta Tbk. Even all crew hold proficiency certificate based on International Ship and Port Facility Security (ISPS) Code, but according to the observation in fact, found there are some crew that do not understand yet with the main principles of security on board the vessel. Procedure of transiting High Risk Area looks like not well understood by all crew and officer. While on other side, security equipments are also available in a very limited quantity and quality. Regarding to this situation, some recommendations proposed such as conduct a regular security drill to make sure that all crew familiar with their own duty and responsibility. A safety meeting is also an effective way to improve knowledge of crew and officer related to security procedure. Company should also involve in preparing security equipments as per regulation especially upon it is requested by the vessel, in order to ensure that vessel will transit High Risk Area securely.
\end{abstract}

Keywords - High Risk Area, ISPS Code, Piracy, Security Awareness

\section{INTRODUCTION}

Nowadays, a crime may be happened not only at shore, but also on the sea that we known it as piracy. Pirates may board the vessel and bidding for cargoes only, or they do a detention to the vessel in order to request redemption. Some of them release the vessel and cargo but hold the crew in secret place. If it is happened outside of the vessel's flag or port of registry, it can disturb the relationship between country and region.

We still remember, case of Sinar Kudus, a cargo vessel operated by PT. Samudera Indonesia which robbed by Somali Pirates on March $16^{\text {th }} 2011$ ago on Arabian Sea. This is the one of so many pirates' activities that needs more attention from all parties. Therefore, understanding about security of the vessel from all crew should be improved. It becomes more important for the vessel that transit High Risk Area such as Arabian Sea started from west of India's beach line until Suez Canal.

Writers found that on board of MT. Bull Sulawesi, there are 3 problems and identified as follows :

1. Lack of awareness of crews about safety and security when passing high risk area;

2. Lack of understanding by crew and officer related to the procedure of transiting High Risk Area especially on Arabian Sea;

3. On other side, the equipment to support increasing of security still in a very limited quantity and quality. In this case, company takes a part to solve the problem.

Data in this paper are based on observation since April $2^{\text {nd }} 2015$ until April $4^{\text {th }} 2016$. Interview was made with competent person on board. Literature study also be made to compare the real situation happened and how it must be happened according to the rules.

\section{FUNDAMENTAL THEORY}

\section{Role of Ship's Crew}

Supriyanto (1996 : 84) said that ship's crew is all personnel who works on board the ship, who has a duty to operate, maintenance, and keep the vessel and its cargo. While according to Suprayitno 
(1993 : 11), role of ship's crew means a series of job and responsibility which is expected to every crew according to each ability whether it is given formally or informally.

On board of the vessel, we know that there is an organization structure to make the responsibility become clearly for each person. Usually vessel is divided by two departments; it is deck and engine department. Vessel is leaded by a Master or usually called as Captain. There are deck officer, engineer officer, deck rating, and engine rating. Additionally, there is a catering part that mostly coordinated under deck department. Every person has their own role whether in normal operation or in an emergency situation including when facing a pirate attack. All crew must familiar with their responsibility.

\section{Piracy}

According the Wikipedia site (id.wikipedia.org/wiki/Perompakan), history of piracy on the sea is started together with the history of navigation. When there are vessels that load merchandise, there will always be a piracy that is ready to have it by force. History of piracy on the sea can't be separated from the long story of pirate on Caribbean Sea and Malacca Strait.

Letter of Decree from Head of Coordination for Sea Security number: SKEP-/ KETUA/ BAKORKAMLA/VI/2011 about Prevention by Company and Master to the Piracy, define that piracy attack is an activity using violence to a ship and her crew, or all trial to attempt boarding the ship and take over the command of the ship. The activity made by other ship also can be concluded as a suspicious activity if one of below happened:

1. Altering course of the ship to our position followed by increasing of speed that considered as abnormal activity for the situation on that area;

2. A small vessel sailing in the same course or direction and in the same speed in an uncommonly time and distance, and that vessel isn't engaged in fishing or other normal navigation activity.

3. Change of course or direction suddenly to our ship with an aggressive behaviour.

The mostly famous pirate activity is Somali Pirate Activity. It is started in early 1990. These pirates exist in the area of Somali waters which is including Indian Ocean, Somali east beach-line, Arabian Sea, and the Gulf of Aden. They ever robbed passenger ship and also cargo vessel. In 2005 they robbed a large tanker with deadweight more than 100.000 tonnes, since than International Maritime Organization and World Food Programme concerned to this issue. They do their activity in many types, start from conventional way until using modern techniques. Usually they use many high speed small ships and assisted by a mother ship that has complete information related to the target. They also use a firearm such as AK-47, RPG-7, and semi automatic gun, even bazooka. They board the vessel by using stairs connected to ship's railing or by ropes. Then they directly come to the bridge to take over the command and ask the Master just to follow what they want.

\section{High Risk Area}

According to book Best Management Practices (BMP) for Protection against Somalia based Piracy (2011), High Risk Area is an area or region that related to its position is dangerous due to mostly happen piracy to the vessel transiting that area.

High Risk Area in this writing is Arabian Sea which is located on the Red Sea (latitude of $15^{\circ} \mathrm{N}$ ), the Gulf of Oman (latitude of $22^{\circ} \mathrm{N}$ ), South Border (latitude of $5^{\circ} \mathrm{N}$ ), and East Border (longitude of $\left.065^{\circ} \mathrm{E}\right)$.

Still according to the Letter of Decree from Head of Coordination for Sea Security, below are the steps that must be done before entering High Risk Area:

1. Company Planning; consist of planning prepared by shipping company to enhance security on board.

2. Master's Planning; consist of planning prepared by Master to enhance security on board.

3. Voyage Planning; consist of navigation planning before entering High Risk Area.

Inside of these three planning, shipping company and Master must conduct a preparation to enter High Risk Area by carrying out below activities:

1. Risk assessment must be made in order to prevent any possibility of piracy and consequences to the vessel according to the last information.

2. Factors that must be included in risk assessment such as: crew safety, minimum freeboard, minimum speed, sea state, and pirates' activity. 
3. Shipping company or Master must be in contact with Navy in IRTC so in case any attack happened, they are ready to assist.

Self Protection Measure (SPM) is made for a guidance which is focus on the preparation according to the ability of each crew to use equipment available. SPM is supported by tools such as dummy of watch keeping person, binocular with night vision optics, candid camera and television (CCTV), weather deck lighting especially in poop/ stern deck, search light, and Safe Muster Point/ Citadel completed with covering tools. Talking about Citadel, is must be strategic place and bullet-proof (Alberto, 2012 : 13). Citadel must be easy to reach by crew and the way to go there is secret, enough air circulation, and possible to make a radio transmission. BMP suggest that the first citadel is engine control room and the second is steering gear room. All crew must familiar to the alarm sounded special for pirate attacks, including how to sound it and what should be done when hearing the alarm. Navigation officer and deck rating in charge of bridge watch keeping must understand about manoeuvring characteristic of the vessel and can use it whenever needed to prevent pirate boarding the vessel.

\section{ISPS Code}

The International Ship and Port Facility Security (ISPS) Code is a code about steps to enhance security to the ship and port facility (imo.org). This code is implemented as response to the threat that can be happened to all vessel and port facility after an attack on September $11^{\text {th }} .2001$ in United States. ISPS Code inserted into The Safety of Life at Sea (SOLAS) Chapter XI-2 as Special Measures to Enhance Maritime Security. This code has 2 parts, these are mandatory and guidance. This code uses risk management approach to ensure security of ship and port facility, also to ensure the proper steps and risk assessment in every case of security. This chapter applies to passenger ships and cargo ships of 500 gross tonnage and upwards, including high speed craft, mobile offshore drilling units and port facilities serving such ships engaged on international voyages. Purpose of this code is to provide standard and consistent framework to evaluate risk and allow government to balance in case any change of threat by fixing proper security level. As part of SOLAS, ISPS Code is mandatory for 148 countries that accepted SOLAS. IMO do not publish a kind of black list, there is no list in IMO for port and flag state that is not compliance. Database of ISPS Code consist information needed by SOLAS regulation $\mathrm{XI}-2 / 13$ as provided by contracting government.

According to ISPS Code, security level can be divided into these 3 levels as follows:

1. Security level 1: normal, the level at which the ship or port facility normally operates. This level means the level for which appropriate protective security measures shall be maintained at all times.

2. Security level 2: heightened, the level applying for as long as there is a heightened risk of a security incident. This level means the level for which appropriate additional protective security measures shall be maintained for a period of time as a result of heightened risk of a security incident.

3. Security level 3: exceptional, the level applying for the period of time when there is credible information that a security incident is probable or imminent. Security level 3 means the level for which further specific protective security measures shall be maintained for a limited period of time when a security incident is probable or imminent, although it may not be possible to identify the specific target. This level should only be set for the duration of the identified security threat or actual security incident. While the security levels may change from level 1, through level 2 to level 3 , it is also possible that the security levels will change directly from level 1 to level 3.

Regulation $\mathrm{XI}-2 / 3$ requires Administrations to set security levels and ensure the provision of security level information to ships entitled to fly their flag. Prior to entering a port, or whilst in a port, within the territory of a Contracting Government, a ship shall comply with the requirements for the security level set by that Contracting Government, if that security level is higher than the security level set by the Administration for that ship.

Regulation XI-2/5 requires all ships to be provided with a Ship Security Alert System.

Regulation XI-2/6 requires all ships to be provided with a ship security alert system, according to a strict timetable that will see most vessels fitted by 2004 and the remainder by 2006. When activated the ship security alert system shall initiate and transmit a ship-to-shore security alert to a competent 
authority designated by the Administration, identifying the ship, its location and indicating that the security of the ship is under threat or it has been compromised. The system will not raise any alarm on-board the ship. The ship security alert system shall be capable of being activated from the navigation bridge and in at least one other location.

Regulation XI-2/8 confirms the role of the Master in exercising his professional judgement over decisions necessary to maintain the security of the ship. It says he shall not be constrained by the Company, the charterer or any other person in this respect.

Regulation XI-2/10 covers requirements for port facilities, providing among other things for Contracting Governments to ensure that port facility security assessments are carried out and that port facility security plans are developed, implemented and reviewed accordingly to the ISPS Code. The biggest change since 1 July 2004 is that the Contracting Governments to the 1974 SOLAS Convention are able to formally exercise of control over ships in accordance with the provisions of chapter XI-2 and of the ISPS Code. At the same time, the Contracting Governments are obliged to address all the objectives and functional requirements of the ISPS Code and to ensure that appropriate security measures and procedures are in place in the port facilities and waterways located within their territory. The new requirements form the international framework through which Governments, ships and port facilities can co-operate to detect and deter acts which threaten security in the maritime transport sector. The new regulatory maritime security regime will have a huge impact for those port facilities and ship operators who had not already taken on board the increased threat to maritime security in the current climate. They will need to catch up, according to the rules and guidelines in the ISPS Code.

For those Governments and ship operators who have already implemented enhanced security regimes, the ISPS Code formalises and standardises globally the security measures. The point is that there is a very real threat. We have already seen attacks on maritime infrastructures elsewhere (such as Yemen and Iraq). The whole idea of the ISPS Code is to reduce the vulnerability of the industry to attack, thus countering the threat and reducing the risk. There are potential commercial benefits to the maritime industry in implementing the Code. It seems clear that, in the long run, implementation of the Code should provide considerable cost-benefit for the port industry as a whole and for individual ports. By putting in place an effective and compliant security regime, ports will be able to continue to participate fully in global trade and, of course, the potential economic consequences of a major security breach, which might result in disruption or even port closure, are serious indeed.

\section{RESULT AND DISCUSSION}

\section{General Description of Observation's Object}

The object of observation is a vessel owned by Gemilang Bina Lintas Tirta Co. And it is chartered due to the company has no own cargo yet. Gemilang Bina Lintas Tirta Co. was established since 2005 as the domestic shipping company and as part of Berlian Laju Tanker Co., the one of the biggest tanker ship's operator in the world which operate the shipping business with international route and domestic route and also improve as the professional shipping company in Indonesia. This company started the business with many of oil tanker ship and gas tanker ship, this is built for carry crude oil and product oil and also gas product like LPG (Liquefied Petroleum Gas). And then this company still continue to improve their business and begin to new segment, like chemical tanker ship and FPSO (Floating Production Storage and Offloading). This company is the only domestic company that own and handling the operations of FPSO. The vision of Gemilang Bina Lintas Tirta Co. is be leading Indonesia's energy of shipping industry and as supplier logistic solution that specializing in sea transportation of oil cargo, offshore service, storage business and agency. The mission of this company is to optimal the interest of stakeholder with comply to costumer's needs in a fair, efficiently and competitive through the provision of quality ships, unit and professional service within strong commitment for safety, security and saving the environment.

MT Bull Sulawesi has 12 cargo tanks with 3 cargo lines that connected with manifolds, where the manifolds are used to connect with hose or loading arm between shore and ship when loading and discharge operation. The connecting parts are named reducer with many kind of size depending of hose that will be connected. When ship is loading, the cargo from shore will pass through manifold 
that will fuel the cargo tanks which prepared to be loaded, and also when ship is discharging the cargo from cargo tanks will passing the manifold before being received by shore. MT Bull Sulawesi has two cargo cranes at the middle of port manifold and starboard manifold for fluency of cargo operation and also to make hose connecting easily that used when cargo operation on SPM (Single Point Mooring) at offshore operation. There is the accommodation consist of 36 cabins, hospital, mess room, boatswain store, chief officer's store, emergency generator room, cargo office room, galley, paint store, laundry room, refrigerator room, engine room, bridge and etc. On board MT Bull Sulawesi has 28 crews include the Master. The crews consist of 4 officers, 4 engineers, 2 boatswains, 1 electrician, 2 fitters, 1 oiler no. 1, 3 quarter masters, 3 oilers, 1 cook, 1 mess boy and 5 cadets ( 3 deck cadets and 2 engine cadets).

\section{Analysis of Observation}

Hereunder, author will discuss the analysis of observation on MT Bull Sulawesi when chartered by Lamda Co. to carry cargo HSFO (High Sulphur Fuel Oil) that loaded at Fujairah, UAE and then will be unloaded at Port Bin Qasim, Pakistan. While ship sailed from Singapore OPL to Fujairah, the ship passing the high risk area at Arabian Sea. When passing this area, appear many problems that felt by crews about the ship's security. From all kind of problems detected, it can be defined and described as follows:

1. Lack of awareness from crews about safety and security when ship is passing high risk area.

As per observation that the author did when ship is passing this high risk area, most of crews don't know yet about the procedure when entering high risk area. This thing make the team aren't ready remembering that they will keep the ship from pirate attack. The ship enters the High Risk Area on July $25^{\text {th }} 2015$ at 22.00 LT. At the moment, Captain starts to give the information and warning to all crew for watch keeping. But, before that Captain asked the crew to join the AntiPiracy Drill. This drill is used to prepare crew and ship when passing High Risk Area. In this thing, Captain is a head leader while Chief Officer is a leader. The information that given to crew are briefing to all crew about the danger of pirate, play the video about the pirate attack and direct action when pirate was on board. The first drill is followed by all crew except that on duty.

The first step, Captain tells code and symbol of danger situation. The Green Code means normal situation but must still do extra watch keeping around the ship. Do the radar observation well, put the lookout man out of the bridge and also always check the door that used for accommodation entrance must be closed. The Yellow Code means the pirate come closer and want to on board. The Red Code means that pirate was on board. And the Captain tells what must do when know the Yellow Code. That is must come together to the bridge and bring the equipment that was given in Muster List: Anti Piracy Drill. And then the Master gives more instruction for ship manoeuvre to duty officer and duty quarter master to make clear from pirate's boat.

Then if it is the Red Code, all crew must direct come together to Citadel. Master must send information or call (if possible) to UKMTO and MSCHOA. The Chief Officer brings all crew to first Citadel. First Citadel on MT. Bull Sulawesi is located in Engine Control Room. Must be remember if will go to Citadel if we are from Cabin, cabin must be locked from outside, so that the pirate can't enter the cabin. If Master and Bridge Team want to leave the bridge, so the Master must activate the Ship Security Alert System, inform the Chief Engineer to shut down fuel and steering power. Don't forget to bring two ways radio telephony for communication and give the duty to the last crew who passing every door to lock the door behind until arrived at Citadel.

Another of Pirate Drill, Master give the instruction to all crew to close the accommodation's window and also lock all the door tightly that used for accommodation entrance. Be careful when do the job outside the accommodation because when ship passing High Risk Area, the sea condition is bad but actually, all crew still don't know what must they do when Anti Piracy Drill. Most of crew still think it is like normal condition instead most of crew join the drill not seriously, when going to Citadel they act normally with talking and also most of crew don't know their duty when come together to Citadel even they already join the drill for many times. When handing over at night there is no security check and fire patrol and the duty officer only fill the Safety Checklist without really check the condition.

According to Chief Alberto as first correspondent, he said: "Actually the crew already know the procedures when ship passing this area, but they almost join in domestic service, so they think 
this situation is normal. Besides of this is a good knowledge for them if they passing this area in another time. I hope this drill can be done again until they understood and do the job well." According the Third Engineer lim Adi Sahputra, as crew who ever passed this area, he said: "I appreciate for this team work. But it still needs more comprehension to all crew. Remind each other, help each other will be the best method to be competent. But they must change their habit. Don't be lazy and must be seriously when join the drill. And keep ship safety and security."

Another problem that will appear in crew is there are still many crew that don't care about the procedures of ship passing High Risk Area. For example, they don't close again the accommodation door and accommodation window in every cabin, installation the water hoses which are not covering all part of the ship but only at specific place, even though the Master often remind it in every safety meeting.

2. Lack of understanding between officer and crew about procedures passing the High Risk Area. It is a new thing about passing this dangerous area among the crews and officers on MT. Bull Sulawesi. This makes less of understanding becoming a main issue. It is recorded that only three crews have ever passed through this area before, they are Capt. Harson Tjolly, Cook Mulatno and $3^{\text {rd }}$ Engineer lim Adi Sahputra. And the other crew just only have heard about high risk area. All of officers have not passed this area yet. This made Master anxious because they are going to be facing the pirates on a case of being followed.

The crew also don't have any knowledge what to prepare before entering this dangerous area, such as installing the razor wire around the ship, installing water hose and putting stand by around the deck, closing all accommodation windows and all accommodation entrance for access. And the crew don't even know the codes when pirates have already on board. The crew don't even know what their duties when there are pirates, where the Citadels are, and what must be done on the way to Citadel.

In the other side the officers don't know the high risk area's limit when passing Arabian Sea. What the report that must be sent, what kind of report, and what times must send the report. According to $4^{\text {th }}$ Officer, Ferry Setiawan, he said: "I still don't know about this thing, I just get the information when passing this area. What must I do when ship is passing this area while I am on duty, so I must ask to Master or Chief Officer first." According to $4^{\text {th }}$ Engineer, Syahrul, he said: "This good experience must I kept very well, because if I enter this area again will make me confident when I'm on duty in engine room. About the Citadel, I still don't even know why it must be in Engine Control Room. I also don't even know when Anti Piracy Drill and what is my job if I am on duty."

3. Limited quantity of security equipment on board.

Due to a lot of regulations that must be fulfilled when ship passing High Risk Area, it gives more job for crew of MT. Bull Sulawesi. Unfortunately, not all equipments that must be installed is available on board because the vessel was only sailing in domestic route. So, it needs more equipment and hard work to prepare the ship before passing this area. For instance, problem exists when installing water hose at ship railing that must direct to ship's side. Most of hoses are not qualified, leaking and can't be fixed to fire line well. The General Service pump that will supply sea water to the deck through water hose just can supply $2-3$ hoses only with pressure that is not maximal. Because when pirate come closer, we must spray around the ship using water hose in order to disturb the pirate that want to come onboard. So if the water pressure is minimal, it's useless and no backstop for the pirate.

Besides of that, installation of razor wire around the ship gets the problem because the condition of razor wire was rusty. Installation of razor wire needs sufficient time because before entering High Risk Area, the ship hits the waves and swells at Andaman Sea and makes installation of razor wire become delay. At a certain place the razor wire can't be putted, like gangway's side because there is no railing nears the gangway's side, so at this side is left empty. Also at panama chock's hole can't be put razor wire.

There is no dummy that can be placed around the ship to deceive the pirates, it makes more problems. Actually the chief officer as safety officer was sent requisitions to the office but no respond yet and no equipment sent on board.

Besides of that, many accommodations' door can't be closed tightly. Ship's performance was old and less maintenance, it makes main accommodations' doors can't closed well, rusty and 
damage that will decrease ship's security. Engine room's door also can't be closed, it makes the access of pirates more easily to enter the engine room. In the regulation, ship must have one place that used as Citadel for safe place from the pirates when on board. First requirement of Citadel is bullet proof. On MT. Bull Sulawesi, first Citadel is in engine control room but actually the engine control room of MT. Bull Sulawesi still standard room and not bullet proof. Second requirement it must have good air circulation. Other Citadel in MT. Bull Sulawesi is in steering gear room that was no good air circulation because the skylight was closed. These make problem if pirate on board and want to hijack the ship. The equipments on the bridge also get problem. Like special Radar for anti piracy watch that can't used anymore after unused for a long time. Function of this Radar is to get target behind the ship, because Radar Scanner's was placed near the aft flag mast and has a blind sector, so using anti piracy Radar is a good choice. Beside Radar, the night vision binocular found only one on the bridge. This causes only one lookout man that can be use night vision binocular at night. While there are two sides of lookout, which is port side and starboard side of bridge. This position is danger for the lookout men because it has no coverage to protect from guns or other attack from pirates.

\section{CONCLUSION AND RECOMMENDATION}

According to observation that the author done, the author concludes some conclusions and gives below recommendations:

1. Most of crew still careless about ship security when passing High Risk Area, this is due to crew was always joining domestic routes which has no strict regulations in security. They consider this situation is just like a normal and they don't care and of course it increases the problem itself.

The officer should warn and talk about this with the crew for making a good responsibility. Discuss about this together if there are problems while following the regulations that has been made. To solve the problems when crew still don't care can be done by reminding together without make the crew felt down.

Periodic anti piracy drill is a good decision to solve this problem. The drill must be done seriously to remind the important action when facing the pirate. So in other time the crew was competent and without nervous in the real situation. Basically, ship safety and security are important thing that crew must know in this situation. The crew should watch and learn what action when sign was ringing. And also should keep awareness when on duty, especially on the bridge, because they must be the first who see the pirate.

Crew should have tolerance and empathy, if there are another crew are careless and still doesn't know. This is making a good impact for safety and security on board. Ask when don't know and share about the importance of keeping secure.

2. Lack of understanding among officers and crew about approaching high risk area procedures can be solved by holding a safety meeting. Sharing session and conversation would give more information and knowledge about approaching high risk area procedure. Especially for the officer that will be a leader in future. This knowledge is rarely given at marine academy. So attendance should be active during safety meeting.

Beside of that, reading navigation book which is related with this dangerous situation could also increase the comprehension about the importance of ship safety and security. BMP4 is the book that specially written to prevent and contain many things about Somali piracy, BMP4 also contain the procedures when ship approaching this area. Watching the movie about ship hijacking such as Captain Philip also makes crew understand about the procedures. By sharing and asking to the crew that has been passing this area will also increase knowledge about procedures when approaching high risk area. This thing makes a better team work on board to maintain safety and security when passing high risk area.

Beside of that, following the instruction from company form such as Passing High Risk Area Form, will make the officers knowing this situation. This makes a new perception for the officer because they are the first person who faced the pirate and the person who make decision of ship manoeuvre when passing this area. 
3. To resolve unavailability safety and security equipments on board such as lack of razor wire, damaged razor wire and the amount of gloves that minimum, Chief Officer as work leader on deck should asking for the requisitions to the office because this has impact to ship security. If the gloves can't be delivered, Chief Officer may propose to buy new gloves when ship is berthing using ship savings. If it can be done, the installation of razor wire may be done by several person only so will make economize gloves usage but if it just be done with a little amount of crew, this make time longer.

To solving the damaged, leaking and not qualified hoses, $3^{\text {rd }}$ Officer as the responsible officer about the safety equipments must check it continuously. It is so important that $3^{\text {rd }}$ Officer can send the requisitions to the office. $3^{\text {rd }}$ Officer ever ask the author to design and repairing leaking hoses with cutting the leaking area (if located at the end of line) and make twist again. If the leaking area located at the middle of line so it can't be used anymore. Other way is to replace the damage hose on deck with good condition hose from accommodation. For General Service Pump problem, Chief Engineer should ask to company for using 2 generators in the same time so it can increase the pressure. Because the ship usually use only 1 generator when ship sailing and 2 generators when ship berthing.

Besides of that, to solve the problem about no dummies on board, Chief Officer should ask to office to deliver it as soon as possible. While awaiting the response from the office, finally Chief Officer has proactive action to make dummies with crew on board by using unused boiler suit and clothes and also cotton rags that arrange into good boiler suit so become dummies, and then putting around the ship's railing. Then using human head shaped pillow and also putting safety helmet and safety shoes.

The damaged doors should be repaired and must be replaced with new door. For the rusty door, it can be chipped or be greased, so make the door can be opened and closed easily.

To resolve problem of malfunction anti piracy radar, all navigation equipment should be checked before sailing in order to maximize the function, especially if it is already known that the vessel will pass pirate's area. If possible, do a self reparation on board as well as the case on MT. Bull Sulawesi which is self reparation done by Electrician and $2^{\text {nd }}$ Officer under agreement from Master on board. The result anti piracy watch radar can be properly used although it can't transmit in certain times. For binocular problem the Master as leader of the ship should ask more binocular to company. In case the damage can't be rectified by crew, it must be called a shore based technicians to fix the problem and make sure the equipment is working properly.

\section{REFERENCES}

[1] International Maritime Organization, 2011, "Best Management Practices for Protection Against Somalia based Piracy (BMP4)", Version 4, London

[2] International Maritime Organization, "International Convention for the Safety of Life at Sea, 1974, as amended (SOLAS 1974)", London.

[3] International Maritime Organization, "International Ship and Port Facility Security (ISPS) Code", London.

[4] Ketua Badan Koordinasi Kemanana Laut Republik Indonesia, 2011, "Surat Keputusan Nomor SKEP-/KETUA/BAKORKAMLA/VI/2011 tentang Upaya Pencegahan oleh Perusahaan dan Nakhoda Kapal terhadap Perompakan", Jakarta.

[5] Noor, Soeharto, 1995, "Metode Penelitian Pendidikan", Transmedia, Jakarta.

[6] PT. Gemilang Bina Lintas Tirta Tbk., 2012, "SMS Manual GBLT Company", Jakarta.

[7] Rosadi, 2012, "Petroleum Tanker Safety", Pertamina, Jakarta.

[8] Suprayitno, Dandung, 1993, "Peran dan Tanggung Jawab Anak Buah Kapal", Transmedia, Jakarta.

[9] Supriyanto, Agus, 1996, “Anak Buah Kapal dan Pekerjaannya”, Alfabeta, Bandung.

[10] Taufik, Mohamad, 2011, "Hakikat Latihan Training", http://penjaskesman26bdg.blogspot.com/ 2011/10/hakikat-latihan-training.html. 